Authors' Contribution

A Study Design

B Data Collection

C Statistical Analysis

D Data Interpretation

E Manuscript Preparation

F Literature Search

G Funds Collection

\section{Imagery use in rehabilitation after the knee joint arthroscopy}

\author{
Dominika WilczyńskaABCDEfG, Anna Łysak ${ }^{A B C D E F G}$, \\ Magdalena Podczarska-GłowackaABCDEFG \\ Gdansk University of Physical Education and Sport, Poland
}

abstract

Background

Material/Methods

Results

Conclusions

Key words
The objective of the study was to assess the efficiency of visualization training based on motivating instructions of a general character in order to increase the knee joint mobility, reduce pain and increase the quadriceps muscle mass of the thigh in patients after the knee joint arthroscopy.

F10 outpatient clinic patients after arthroscopy of the knee joint (average age $35 \mathrm{yrs}$ ) were subject to research. Physiotherapeutic treatment comprised an improvement program to increase the range of flexion in the knee joint (full ROM), align limbs circumference and reduce pain. The research group was divided into 2 subgroups. In group I, the control group, improving exercises and physical treatment were applied, while in group II, the experimental one, improvement and physical treatment program was expanded with visualization. The sample selection was random.

The research showed that, irrespective of the time after operation, the experimental group felt less pain than the control one, when the latter used classical methods of joint improvement. It was also stated that regardless of the time after operation, the group using visualization achieved greater improvement in the knee flexion than the standard group. The scientists also claimed that the increase in post-operative limb circumference depended on the applied therapeutic method. In the group with a visualization program a linear growth of limb circumference with the passage of time was observed. The experimental group achieved greater improvement in the post-operative leg circumference than the control group.

The study shows that visualization may be an effective supplement of a therapeutic procedure; however, deeper evaluation of its efficacy at different stages of patient's improvement requires further research and observations.

\section{visualization training, knee joint, mobility, pain, arthroscopy, quadriceps, muscle mass}

article details

Article statistics

Full-text PDF:

Copyright

Indexation:

Funding:

Conflict of interest: Corresponding author:

Open Access License:
Word count: 2,160; Tables: 1; Figures: 5; References: 34

Received: February 2015; Accepted: September 2015; Published: December 2015

http://www.balticsportscience.com

(๑) Gdansk University of Physical Education and Sport, Poland

AGRO, Celdes, CNKI Scholar (China National Knowledge Infrastructure), CNPIEC, De Gruyter - IBR (International Bibliography of Reviews of Scholarly Literature in the Humanities and Social Sciences), De Gruyter - IBZ (International Bibliography of Periodical Literature in the Humanities and Social Sciences), DOAJ, EBSCO - Central \& Eastern European Academic Source, EBSCO - SPORTDiscus, EBSCO Discovery Service, Google Scholar, Index Copernicus, J-Gate, Naviga (Softweco, Primo Central (ExLibris), ProQuest - Family Health, ProQuest - Health \& Medical Complete, ProQuest - Illustrata: Health Sciences, ProQuest - Nursing \& Allied Health Source, Summon (Serials Solutions/ProQuest, TDOne (TDNet), Ulrich's Periodicals Directory/ulrichsweb, WorldCat (OCLC)

This research received no specific grant from any funding agency in the public, commercial, or not-for-profit sectors.

Authors have declared that no competing interest exists.

Dr Dominika Wilczyńska, Gdansk University of Physical Education and Sport, ul. Kazimierza Gorskiego 1, 80-336 Gdansk, Poland Phone number: +48504050675; e-mail: domiwilczynska@gmail.com

This is an open access article distributed under the terms of the Creative Commons Attribution-Non-commercial 4.0 International (http://creativecommons.org/licenses/by-nc/4.0/), which permits use, distribution, and reproduction in any medium, provided the original work is properly cited, the use is non-commercial and is otherwise in compliance with the license. 


\section{INTRODUCTION}

Arthroscopy is the most frequent procedure in diagnosis and therapy of the biggest and most susceptible to damage and overload knee joint. Its complex construction, location and primarily biomechanics of work (femoral-tibial and patellar-femoral joints have 6 degrees of freedom, and combination of movements takes place in three axes) decide that $15-30 \%$ of all body injuries affect the knee joint [1, 2]. In sport this statistics is even higher and fluctuates between $23-70 \%[3,4]$. Quick recovery, including daily and recreational activity, and in some cases sport activity, require both precise arthroscopy and optimal, return-oriented function and, preferably, an individualized rehabilitation model [5].

There are many works on principles of rehabilitating a patient after surgeries on the knee joint $[6,7,8,9]$. Among well-known therapeutic methods, however not used in everyday practice, is mental visual imaging training [10], e.g. perfecting a physical skill by mental creation or recreation of perceptual functions. The present authors attempted to assess the effectiveness of this method as a supplement to classical physiotherapy. It is based on sensual, visual, flavour, kinaesthetic, smell and hearing visualizations. Imaginary training, also called visualization, is one of efficient tools in the form of planned and systematic interactions in contemporary types of psychotherapy, e.g. the Solution Focused Brief Therapy or the Cognitive Behavioural Therapy. It is also a tool in mental training in sport, as an exercise performed during injury in order to accelerate the rehabilitation process and return to sport disposition $[11,12,13]$.

Visualization is a method in which optional or controlled visions of an oriented character are used, when a psychologist or physiotherapist leads a patient through suggested situations [13]. Visualization in physiotherapy, just as in sport, might have a general or specialist motivating or cognitive character. For the needs of the present study general motivating visualization was applied to increase the patient's control of the injured joint and confidence. Visualization training may refer to training, competition or rehabilitation after a surgery or a contusion $[14,15]$. It becomes more important as a supplementary form of physiotherapeutic treatment used in order to let the patient return to an active life after an injury, at the same time developing self-confidence and lowering anxiety in patients. Research on sportsmen shows that when they visualize performing rehabilitation exercises making use of the sensory canal, e.g. a kinaesthetic sense, which allows them to reproduce a physical feeling of movement, their confidence and motivation for rehabilitation grow. Patients - competitors performing visualization emphasize that they feel more positive and relaxed [16]. The study also shows that if we implement visualization into physiotherapeutic treatment in sportsmen it contributes to better treatment outcomes, quicker adaptation to the whole course of rehabilitation, greater self-efficacy and pain reduction [15, 17].

\section{OBJECTIVE OF THE STUDY}

The objective of the study was to assess the effectiveness of a classical therapeutic procedure supplemented with visualization in patients after arthroscopy of the knee joint in improving the knee joint mobility, reducing pain and increasing body mass of the quadriceps muscle in the thigh. 


\section{MATERIAL AND METHODS}

10 outpatient clinic patients after arthroscopy of the knee joint (mean age 35 yrs) were subject to research. The conducted operations included sewing the medial meniscus (3 patients), reconstructing the anterior cruciate ligament (3 patients), the anterior cruciate ligament surgery ( 2 patients), patellar luxation and diagnosis of the articular cartilage. A test procedure was implemented after relief of soft tissue inflammation in the knee joint and when full extension of the knee was observed: in 7 patients in the fourth week and in 3 patients in the fifth week after the surgery. The test lasted for 3 consecutive weeks except Saturdays and Sundays (15 treatment days). The improvement program was implemented into the physiotherapeutic treatment in order to achieve a gradual increase in the knee joint flexion (full ROM), align the limb circumference, reduce pain, regain proprioception, which in turn would allow gait re-education, full recovery and return to every day activity.

The research sample was divided into two groups. Group I exercised in open and close kinematic chains and performed Ugul cage exercises (using customised resistance), post-isometric relaxation of hamstring and quadriceps muscles, neuromobilization of the femoral nerve, proprioception training, aqua gymnastics, functional massage of the quadriceps and patellar mobilization. Physiotherapeutic treatment consisted of electrostimulation of the quadriceps muscle, magnetic therapy, laser and cryotherapy with liquid nitrogen. The above mentioned procedure was supplemented in Group II by a method of perfecting physical skills through mental reproduction of postoperative limb movements, e.g. visualization focused on functional recovery and full efficiency. Visualization had a general, motivating and kinaesthetic character: 'I feel as every little part of this ligament slowly heals. I feel as it fuses as well. It allows the knee to function smoothly' and an external character: 'I see my knee. I imagine it myself. The whole knee is surrounded by strong ligaments' [18]. The instructions were to accelerate a rehabilitation process and recovery through bigger self-efficacy in postoperative mobility of the knee in the patients from the experimental group. The tool was developed by a sport psychologist, Kamil Wódka, PhD, for the purposes of individual work with a female Alpine skier after arthroscopy of the knee. Visualization was applied every time before the improvement program. The instructions were read every time by a physiotherapist (15 visualization sessions). The sample selection was random. The subgroups are presented in Table 1 .

Table 1. Research sub groups with applied improvement procedure and evaluated parameters.

\begin{tabular}{|c|c|c|}
\hline Group I $(n=5)$ & \multicolumn{2}{|l|}{ Group II $(n=5)$} \\
\hline \multirow{2}{*}{ Physical therapeutic methods } & \multicolumn{2}{|c|}{ Physical therapeutic methods } \\
\hline & \multicolumn{2}{|c|}{+} \\
\hline (terminology in statistics"physiotherapy") & \multicolumn{2}{|c|}{$\begin{array}{l}\text { Visualization (terminology in statistics "physiotherapy } \\
\text { and visualization") }\end{array}$} \\
\hline \multicolumn{3}{|l|}{ Parameters } \\
\hline Mobility of the knee joint & \multirow{3}{*}{$\begin{array}{l}1^{\text {st }} \text { day of the therapy }(n=10) \\
6^{\text {th }} \text { day of the therapy }(n=10) \\
15^{\text {th }} \text { day of the therapy }(n=10)\end{array}$} & Mobility of the knee joint \\
\hline Thigh circumference & & Thigh circumference \\
\hline Laitinen pain scale & & Laitinen pain scale \\
\hline
\end{tabular}


Evaluation was based on limb circumferences $(6$ and $10 \mathrm{~cm}$ from the patella base) measured in degrees of the range of motion of the postoperative knee joint and the modified Laitinen Pain Scale, LPS [19] (4 - unbearable pain, 0 - no pain). The collected data ( 6 and $10 \mathrm{~cm}$ from the patella base) allowed creating an average circumference of the limb used in further analyses. Participation in the research was voluntary, and all the patients were informed about the applied therapy, signed the treatment agreement and consent to be included in the study. IBM SPSS Statistics v20, Microsoft Excel 2010A computer program and the analysis of variance (ANOVA) were used for statistics. Significance of differences was determined at $\mathrm{p}<0.05$.

\section{RESULTS}

The reduction of pain was irrespective of the therapeutic method. It is proved by a negligible effect of interaction $F(2,16)=0.88, p=0.436$. It shows that the dynamics of changes were equal in both groups (the 2-way analysis of variance (ANOVA) in a mixed scheme. Regardless of the group, the level of pain lowered over time $F(2,16)=61.25, p<0.05$. The patients felt the strongest pain on the $1^{\text {st }}$ day of treatment $(M=3.20, S D=0.63)$, a lower intensity was observed after 1 week $(M=2.40, S D=0.52)$, and the lowest one after 3 weeks $(M=0.70, S D=0.48), p<0.05$. The research results also showed that regardless of the time after the surgery the patients from the experimental group felt less pain $(M=1.86, S D=0.33)$ than those in the group with a classical model of mobility improvement $(M=2.33, S D=0.18), p<0.05$.

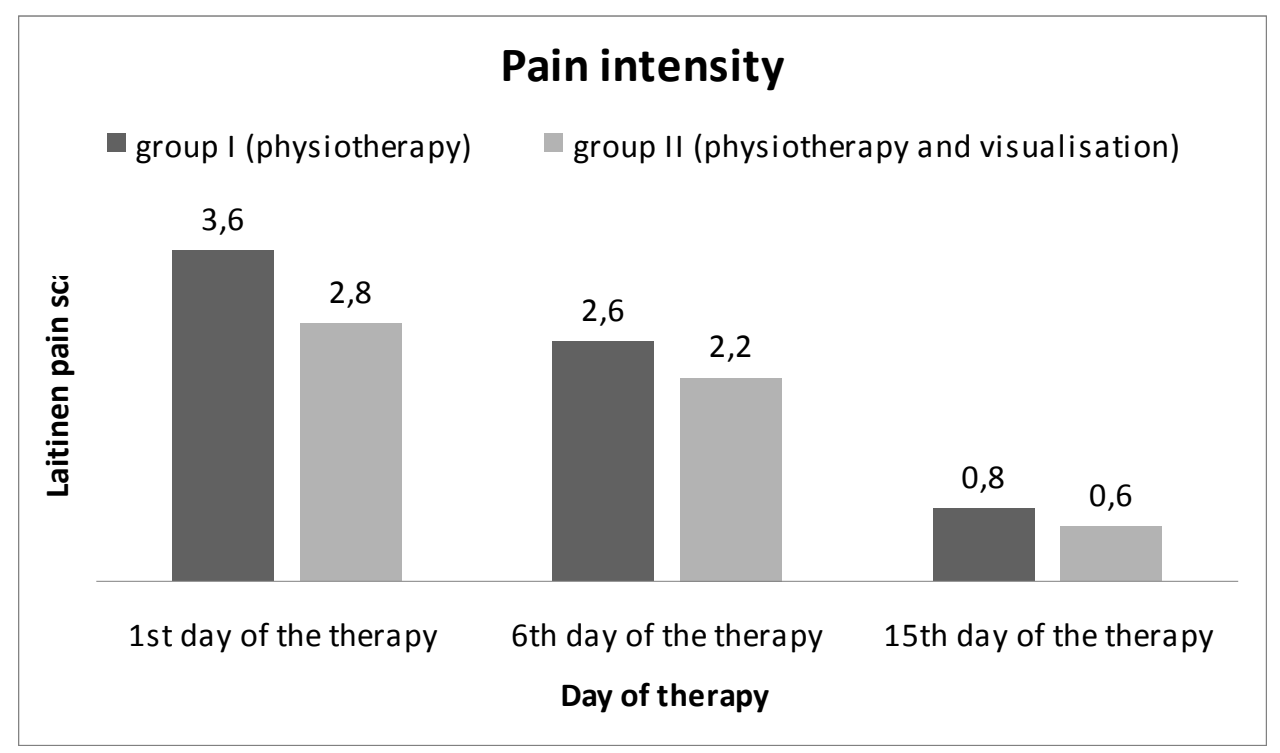

Fig. 1. The level of pain depending on the time and the type of treatment

Post-operative increase in limb mobility is independent of the type of a therapeutic method. A negligible effect of interaction $F(2,16)=15.83, p=0.902$ proves the above. The range of mobility increases over time irrespective of the group: $F(2,16)=23.20, p<0.05$, and patients presented the most limited mobility of limbs on the $1^{\text {st }}$ day of treatment $(M=81.00, S D=30.98)$. After 1 week the mobility grew $(M=102.00, S D=22.26)$ to reach the highest 
level of ROM after 3 weeks $(M=118.50, S D=30.34), p<0.05$. The results showed that regardless of the time after the surgery the experimental group using visualization achieved better improvement in the knee flexion than the standard group $F(1,8)=199.79, p<0.05$.

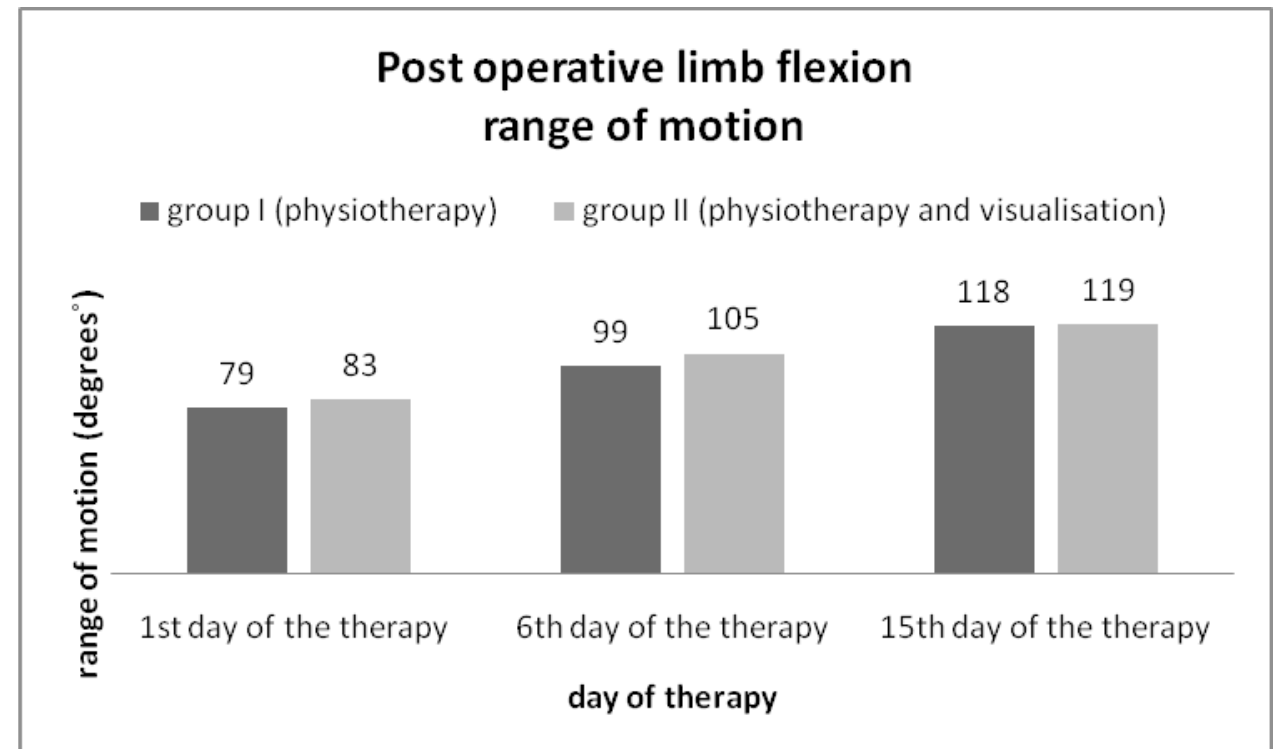

Fig. 2. The range of postoperative knee flexion depending on the time and the type of treatment

In addition, after a 3-week course of treatment the patients were not able to achieve similar ranges of motion in comparison to the ROM level in the knee joint which was not subject to operation (the mean value of this variable was \pm 136 degrees for the knee flexion).

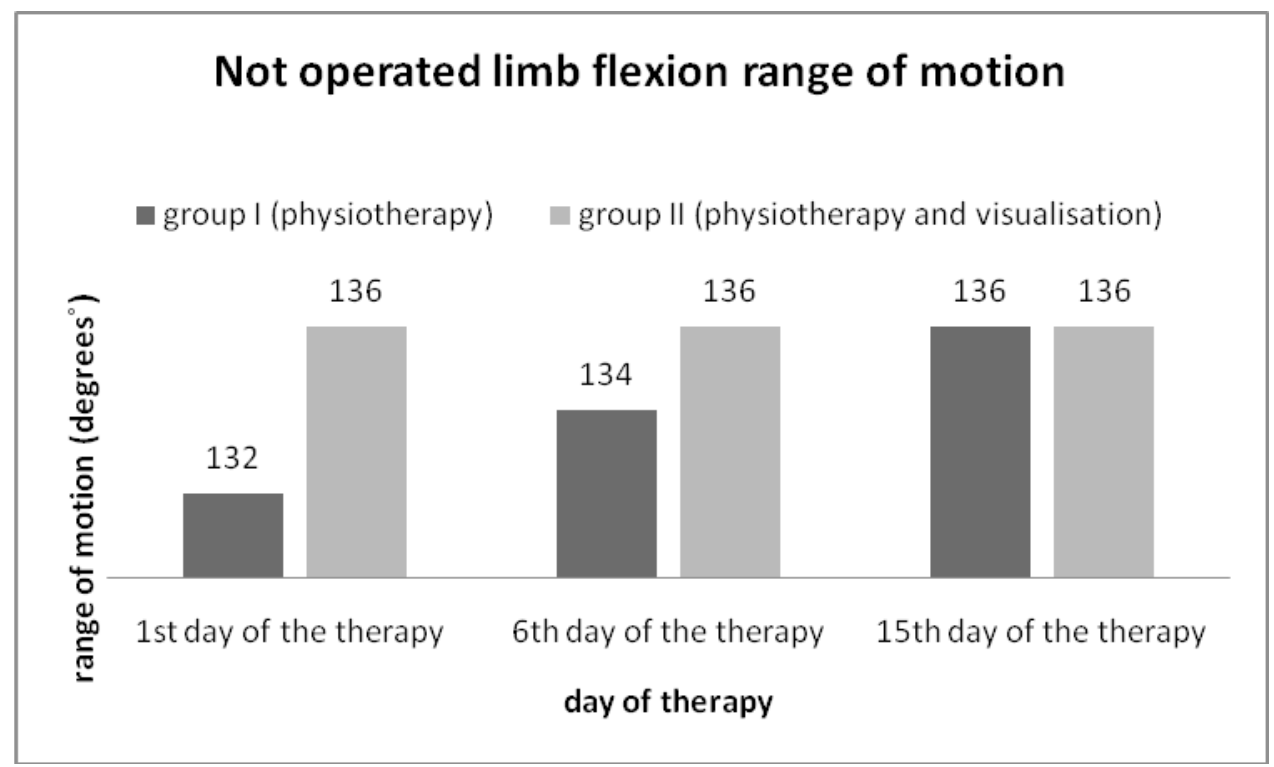

Fig. 3. The range of flexion in the not operated knee joint depending on the time and the type of treatment

Increase in the circumference in the operated knee depended on the therapeutic method. In the test group, taking visualizationinto account, the linear growth ofthe limb circumference with time was noted. Such a dependence 
has not been confirmed in the group with standard treatment. Irrespective of the time after surgery the group using visualization achieved better improvement in terms of changes in the post-operative limb circumference than the standard group $F(2,16)=30.90, p<0.05$.

Fig. 4. Postoperative limb circumference depending on the time and the type of treatment

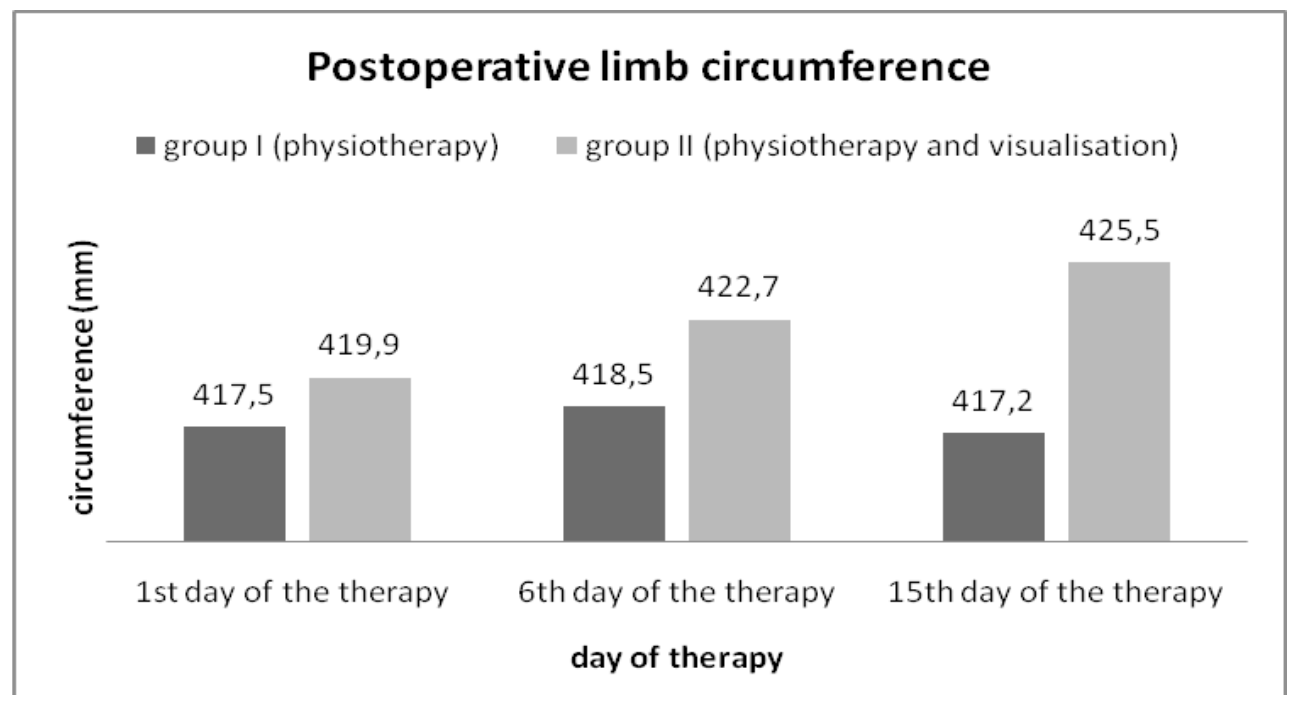

It was proved that the therapeutic impact was not limited to the limb after arthroscopy. An increase in the limb circumference was independent of the type of therapeutic treatment, which is indicated by an insignificant effect of interaction $F(2,16)=1.48, p=0.258$. The complexity of procedures in the study is shown by the fact that muscle growth of a thigh referred both to the operated and not operated limb. Also in each case, regardless of the time of measurement, significant differences in circumferences of both limbs were noted; at the same time, in Group II, in which visualization was used, the circumference of the post-operative limb was approaching the level of the not operated limb with each subsequent measurement.

Fig. 5. Not operated limb circumference depending on the time and the type of treatment

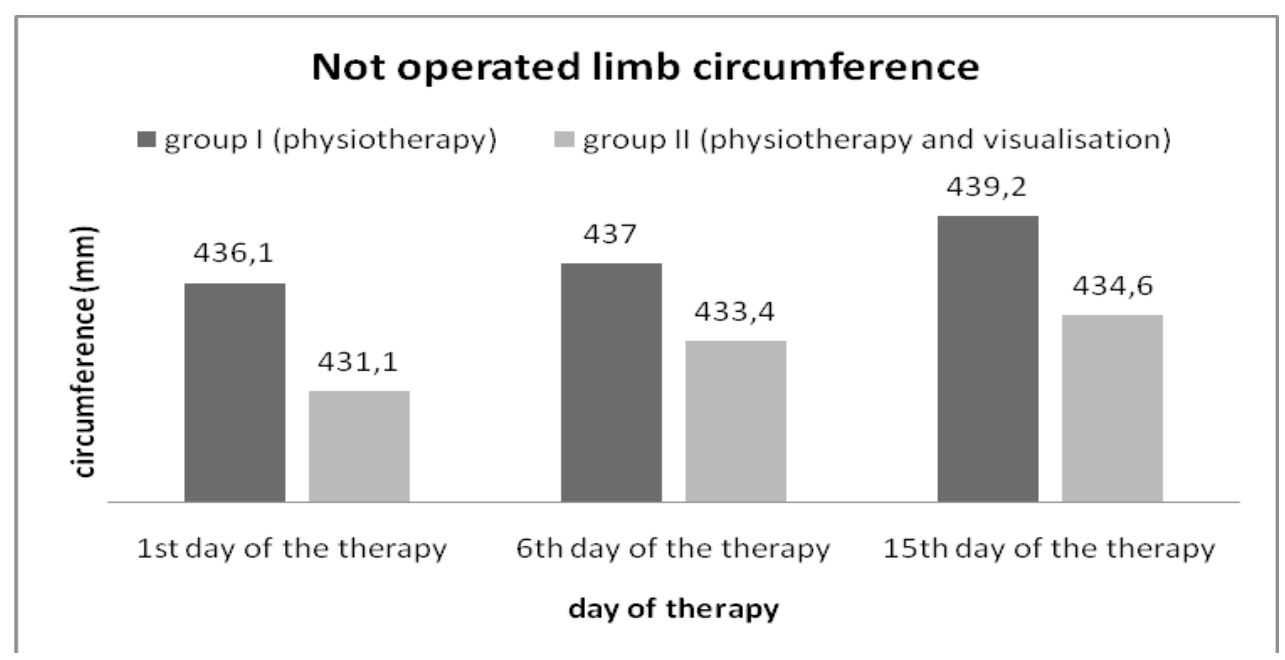




\section{DISCUSSION}

The obtained results showed that better effects in the process of improvement and the quest for pre-injury efficiency in the patients after the knee joint arthroscopy are yielded by a mixed therapy, i.e. physiotherapy with visualization. Similar observations have been made by other authors, including Hamson [20], Evans et al. [21] and Sardoniet al. [23]. They show, among others, a possibility to implement visualization training at various stages of patient's rehabilitation and refer to them as early, medium and late stages [23].

It has to be emphasised that visualization training (ideomotoric) is one of the most effective tools used by physiotherapists, coaches and, primarily, by psychologists. The technique itself makes use of patients' abilities of sensory perceptions, visual, hearing, kinaesthetic, flavoured or olfactory ones, to create pictures, make opinions about a situation or a person, an object or a part of the body (in the presented case - the knee joint) and equips them with attributes of authenticity even in a situation which is not an exact reflection of reality (post-injury state, arthroscopy).

Mental images resulting from a reflexion or a transformation of reality may influence the patients' functional state; moreover, when reducing or increasing the psychophysical stimulation they may affect one's emotional states and create opinions about themselves and other people [22]. During the initial stage of improvement, most often accompanied by pain, swelling, reflex muscle tension, and lack of physiological mobility, adding visual training to a traditional model of mobility improvement would primarily help to increase pain control, lower effusion, swelling and inflammation. Additionally, it could prevent postoperative adhesion, the patellar/femoral conflict and, as a consequence, improve joint mobility, help regain muscle control, proprioception, and subsequently stabilization of the knee joint. In the subsequent stages of rehabilitation the previously defined goals should be continued: tendency towards regaining muscle strength and a normal gait pattern. The patient would come back to work and every day activities would then be prepared to return to recreational activity or sport $[25,26,27,28]$.

The key role in mental visualization in the following rehabilitation stages is played by visualization of purposes as well as by motivating activity. It is very important for the final stage of rehabilitation to reduce the fear of re-injury. Mental images at this stage contain numerous verbal and visual guidance (positive reinforcement) which facilitate full utilization of an earlier damaged joint. A classical model of improvement after knee arthroscopy supplemented by visualization training eases indication and conscious realization of goals appropriate for the specific stage of rehabilitation, conscious observation and correcting one's own reactions and analysing mistakes. In addition, visualization training may be advantageous for reducing the risk of accidental decisions about undertaking and realization of motor tasks, lengthening the concentration time, increasing mental strength, reducing the fear of injury, supporting a positive attitude, which may help the recovery process and return to everyday activities [24, 29]. Moreover, research shows that guided visualization can be a favourable factor to control pain by patients [30, 31], which may affect endorphin increase [32]. There are also studies which show that if we add visualization to the rehabilitation process, it will increase the patients' level of well-being [31, 33, 34]. 


\section{CONCLUSION}

In order to provide the highest effectiveness in regaining pre-injury performance in the improvement process of a patient after the knee joint arthroscopy it is recommended to use a visualization method next to a classical therapeutic approach.

\section{REFERENCES}

[1] Dziak A. Uszkodzenia więzadeł krzyżowych kolana [Cruciate ligaments lesions]. Acta Clinica. 2001;1(4):269-274. Polish.

[2] Kochański B, Łabejszo A, Kałużny K, et al. Knee injury - a diagnostic procedure. Journal of Health Sciences. 2013;3(5):439-456.

[3] Nagraba Ł, Okrzeja A, Mitek T. Uszkodzenia więzadła krzyżowego przedniego u sportowców [Injuries of the anterior cruciate ligament in athletes]. Arthroscopy and Joint Surgery. 2011;7(1-2):11-17. Polish.

[4] Widuchowski J. Diagnostyka obrażeń stawu kolanowego u sportowców [Injuries of the knee joint in athletes - diagnostic evaluation]. Medicina Sportiva 2005;9(4):293-302. Polish.

[5] Czechowska D, Milert A, Golec J, Szczygieł E, Golec E. Ocena wyników rehabilitacji chorych po częściowej resekcji łąkotki przyśrodkowej stawu kolanowego w oparciu o autorski program usprawniania [Effect of physiotherapy based on authors' own rehabilitation program in patients after partial resection of the medial meniscus of the knee]. Kwartalnik Ortopedyczny. 2012;4:479-488. Polish.

[6] Stolarczyk A, Kurdziel J, Nagraba Ł, Miotek T, Nowak P. Wpływ fizjoterapeutycznego postępowanian a wyniki leczenia uszkodzeń więzadła krzyżowego przedniego w zależności od okresu, w jakim wykonano rekonstrukcję [Anterior cruciate ligament injury: The influence of physiotherapy on the operative treatment results, depending on the time of the ACL reconstruction]. Arthroscopy and Joint Surgery. 2009;5(2):11-24. Polish.

[7] Dias JM, Mazuquin BF, Mostagi FQ, et al. The effectiveness of postoperative physical therapy treatment in patients who have undergone arthroscopic partial meniscectomy: systematic review with meta-analysis. Journal of Orthopaedic and Sports Physical Therapy. 2013;43(8):560-76.

[8] Goodwin PC, Ratcliffe J, Morrissey MC. Physiotherapy after arthroscopic partial meniscectomy surgery: an assessment of costs to the National Health Service, patients, and society. Int J Technol Assess. 2005;21(4):452-8.

[9] Morrissey MC, Milliqan P, Goodwin PC. Evaluating treatment effectiveness: benchmarks for rehabilitation after partial meniscectomy knee arthroscopy. Am J Phys Med Rehab. 2006;85(6):490-501.

[10] Jankowska S. Potęga umysłu, czyli doping doskonały. [The power of the mind, an excellent doping]. In: Annales Academiae Medicae Stetinensis - Neurokognitywistyka w Patologii i Zdrowiu 2011-2013. Szczecin: Pomorski Uniwersytet Medyczny w Szczecinie; 2013, 99-104. Polish.

[11] Lazarus A. Wyobraźnia w psychoterapii. Podstawowe techniki. [Imagery inpsychotherapy. Basic techniques]. Gdańsk: GWP; 2000. Polish.

[12] Curwer B, Palmer S, Ruddell P. Poznawczo-behawioralna terapia krótkoterminowa. [Cognitive-behavioural short-term therapy]. Gdańsk: GWP; 2005. Polish.

[13] Zapotoczna D. Wyobraź sobie siebie! Wizualizacja jako narzędzie rozwoju w sporcie. [Imagine yourself! Visualization as a tool for sport development]. Magazyn Trenera. 2012;20:18-21. Polish.

[14] Martin KA, Moritz SE, Hall CR. Imagery use in sport: A literature review and applied model. The Sport Psychologist. 1999;13:245-268.

[15] Hare R, Evans L, Callow N. Imagery use during rehabilitation from injury: a case study of an elite athlete. The Sport Psychologist. 2008;22:405-422.

[16] Sordoni CA, Hall CR, Forwell L. The use of imagery by athletes during injury rehabilitation. Journal of Sport and Rehabilitation. 2000;9:329-338.

[17] Wesch N, Hall C, Prapavessis H, et al. Self-efficacy, imagery use, and adherence during injury rehabilitation. Scandinavian Journal of Medicine and Science in Sports. 2012;22:695-703.

[18] Nowicki D. Trening relaksacyjny i wyobrażeniowy w procesie przygotowania startowego. [Visualization and relaxation training during preparation period in sport]. In: Kłodecka-Różalska J, editor. Przekraczanie umysłem możliwości ciała. [Using mind to overcome body abilities]. Warszawa: COS; 1996. Polish.

[19] Dobrogowski J, Sedlak K. Ocena kliniczna chorego z bólem przewlekłym [Clinical evaluation of a patient with chronic pain]. In: Dobrogowski J, Kuś M, Sedlak K, Wordliczek J, eds. Ból i jego leczenie [Pain and its treatment]. Warszawa: PWN; 1996. Polish.

[20] Hamson J. The effects of mental imagery on recovery time and adherence to sport-injury rehabilitation programs of college athletes. Salt Lake City, Utah: American Alliance for Health, Physical Education, Recreation and Dance; April 2006.

[21] Evans L, Hare R, Mullen R. Imagery use during rehabilitation from injury. Journal of Imagery Research in Sport and Physical Activity. 2006;1(1):1-19.

[22] Sordoni CA, Hall CR, Forwell L. The use of imagery in athletic injury rehabilitation and its relationship to self-efficacy. Physiotherapy Canada. 2002;54:177-185. 
[23] Wesch N, Prapavessis H, Maddison R, et al. Self-efficacy, imagery use, and adherence during injury rehabilitation. Scandinavian Journal of Medicine \& Science in Sport. 2011;5:695-703.

[24] Griffin LY, editor. Rehabilitation of the injured knee. 2nd edition. St Louis: Mosby; 1995, 81-85.

[25] Hooper D, Morrissey M, Drechsler W, Morrissey D. Open and closed kinetic chain exercises in the early period after Anterior Cruciate Ligament reconstruction. The American Journal of Sports Medicine. 2001;29(2):167-174.

[26] Rudolph K, Axe M, Buchanan T, Scholz J, Snyder-Mackler L. Dynamic stability in the anterior cruciate ligament deficient knee. Knee Surgery, Sports Traumatology, Arthroscopy. 2001;9(2):62-71.

[27] Solomonow M, Krogsgaard M. Sensorimotor control of knee stability. A review. Scandinavian Journal of Medicine and Science in Sports. 2001;11:64-80.

[28] Tietjens B. Return to sport following ACL reconstruction. In: ISAKOS 2001 Symposium, May 14-18. 2001. Montreux, 2001.

[29] Driediger M, Hall C, Callow N. Imagery use by injured athletes: A qualitative analysis. Journal of Sports Sciences. 2006;24:261-271.

[30] Deisch P, Soukup SM, Adams P, Wild MC. Guided imagery: replication study using coronary artery bypass patients. Nursing Clinics of North America. 2000;35(2):417-425.

[31] Dreher II. Mind-body interventions for surgery: Evidence and exigency. Advances in Mind-Body Medicine. 1998;14:207-222.

[32] Thomas BL. Pain management for the elderly: Alternative interventions. AORN Journal. 1991;53:126132.

[33] Devine KC, Cook TD. Clinical and cost-savings effects of psychoeducational interventions with surgical patients. A meta-analysis. Research in Nursing and Health. 1986;9:89-105.

[34] Oyku O. Guided imagery as a psychotherapeutic mind - body intervention in health psychology: A brief review of efficacy research. Europe's Journal of Psychology. 2012;4:227-237. 